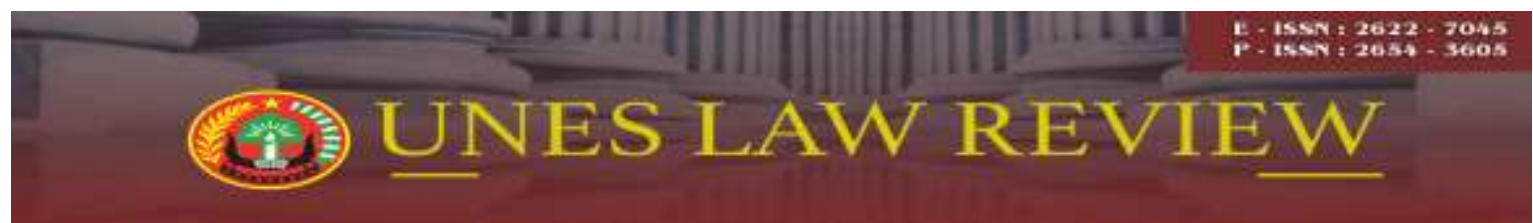

Email: uneslawreview@gmail.com

Online: http://review-unes.com/index.php/law

Volume 2, Issue 1, September 2019

\title{
EKSISTENSI KEPOLISIAN SEKTOR DALAM MEWUJUDKAN KEAMANAN DAN KETERTIBAN MASYARAKAT DI NAGARI KURANJI HILIR DAN KOTO TINGGI KABUPATEN PADANG PARIAMAN
}

\author{
Kasman \\ Anggota Polri, Polda Sumatera Barat, Indonesia \\ E-mail : $\underline{\text { Kasman.67@ gmael.com }}$
}

\begin{abstract}
According to Article 13 of Law No. 2 of 2002, the main task of the National Police is to maintain public security and order, uphold the law and provide protection, protection and service to the community. Placement in the lurah / village and nagari is the Existence of Sector Police Implementation in realizing the security and order of the people of Nagari Kuranji Hilir and Koto Tinggi Kabupaten Padang Pariaman is the Implementation of Kapolri Regulation Number 3 of 2015. The approach model implemented by Sector Police is a model of community policing arrogance (Community Policing). The formulation of the problem in the study is, first, How the Existence of the Inner Sector Police Realizes the Security and Order of the Nagari Kuranji Hilir Community and Koto Tinggi Kabupaten Padang Pariaman? Padang Pariaman? what three efforts should be corrected in the Existence of the Sector Police in Realizing the Security and Order of the Nagari Kuranji Hilir Community and Koto Tinggi Kabupaten Padang Pariaman? This research is a legal research wicth analysis descriptive specification. The approach used is a normative Juridical approach supported by an empirical Juridical approach. The data used are secondary data and primary data collected through library studies and field studies. The data is then analyzed qualitatively and presented in the form of descriptive qualitative. The conclusions of the study are, First, the Existence of Sector Police in Realizing the Security and Order of Nagari Kuranji Hilir and Koto Tinggi Communities Sungai Limau District, Padang Pariaman Regency is carried by the Existence of Bhabinkamtibmas by adopting local wisdom, pre-emptive efforts, pam swakarsa development, forming community policing, FKPM and Pokdar Kamtibmas, Do Problem Solving through the ADR pathway; Second, the constraints in the implementation faced by the Sector Police in Realizing the Security and Order of the Nagari Kuranji Hilir Community and Koto Tinggi Sungai Limau Subdistrict, Padang Pariaman Regency, are citizens' legal awareness which tends to view a win lose solution, area, demography and geography have hills, rivers and lurahs. ratio ratio 1: 3,000. and third Efforts to overcome obstacles to implementation Existence of Sector Police in Realizing Security and Order The people of Nagari Kuranji Hilir and Koto Tinggi of Kabupaten Padang Pariaman are Polri publishing Smart Books on Bhabinkamtibmas, Increasing Knowledge, Bhabinkamtibmas such as Training and vocational education.
\end{abstract}

Kata Kunci: Eksistensi, Ketertiban Masyarakat, Keamanan 


\section{PENDAHULUAN}

Sejak era reformasi yang dimulai pada tahun 1998, telah terjadi banyak perubahan penting di berbagai bidang kehidupan masyarakat, yang selanjutnya menjadi tonggak dimulainya era reformasi gelombang pertama. Perubahan ini dilandasi oleh keinginan sebagian besar masyarakat untuk mewujudkan pemerintahan yang demokratis dan mempercepat terwujudnya kesejahteraan rakyat yang didasarkan pada nilai-nilai dasar sebagaimana tertuang dalam Pembukaan Undang Undang Dasar Negara Republik Indonesia Tahun 1945.

Momen ini menjadi titik awal dimulainya proses reformasi di tubuh Kepolisian Negara Republik Indonesia (Polri) secara menyeluruh menuju Polri yang profesional dan mandiri serta sesuai dengan tuntutan dan harapan masyarakat, yang mencakup 3 (tiga) aspek integral bidang struktural, instrumental dan kultural. Pada perkembangannya reformasi di bidang birokrasi mengalami ketertinggalan dibanding reformasi di bidang politik, ekonomi dan hukum, sehingga pada tahun 2004, pemerintah telah menegaskan kembali akan pentingnya penerapan prinsip-prinsip pemerintahan yang bersih (clean government) dan tata kelola pemerintahan yang baik (good governance), yang secara universal diyakini menjadi prinsip untuk memberikan pelayanan prima kepada masyarakat.

Pencegahan menjadi penting sebab sering kali upaya represif hanya mengutamakan kepastian hukum dan terkadang mengabaikan rasa keadilan masyarakat maka perlu adanya peningkatan upaya pre-emtif (himbauan) dan preventif (pencegahan) dalam memberikan pelayanan terhadap masyarakat bidang keamanan dan ketertiban masyarakat.Untuk membangun organisasi yang tepat fungsi yang berorientasi kepada pelayan masyarakat, perlu adanya langkah dan upaya agar organisasi tersebut sesuai dengan harapan masyarakat.

Terkait dengan peningkatan kualitas pelayanan publik sekaligus sebagai upaya untuk menjaga situasi keamanan dan ketertiban masyarakat, Polres Pariaman Mengimplementasikan "Penempatan Bhayangkara Pembina Keamanan Ketertiban Masyarakat yang disingkat dengan Bhabinkamtibmas di kelurahan/desa dan nagari untuk Mewujudkan Keamaman dan Ketertiban Masyarakat kelurahan/desa dan nagari” yang artinya menempatkan satu orang anggota Polri di setiap desa/nagari untuk Mewujudkan Keamaman dan Ketertiban Masyarakat nagari. Penempatan Bhabinkamtibmas di 
kelurahan/desa dan nagari merupakan Implementasi dari Peraturan Kepala Kepolisian Negara Republik Indonesia Nomor 3 Tahun 2015 tentang Pemolisian Masyarakat, dalam peraturan ini mengenai Bhabinkamtibmas diatur pada bagian kedua dari Pasal 25 sampai dengan Pasal 31.

Undang undang Dasar Negara Republik Indonesia 1945 Bab XII tentang Pertahanan dan Keamanan Negara Pasal 30 ayat (4) UUD 1945: "Kepolisian Negara Republik Indonesia sebagai alat negara yang menjaga keamanan dan ketertiban masyarakat bertugas melindungi, mengayomi, melayani masyarakat, serta menegakkan hukum”

Pasal 13 Undang-undang Nomor 2 Tahun 2002 tentang Kepolisian Negara Republik Indonesia, menjelaskan tentang tugas pokok Kepolisian Negara Republik Indonesia adalah:

1. Memelihara keamanan dan ketertiban masyarakat

2. Menegakkan hukum dan

3. Memberikan perlindungan, pengayoman dan pelayanan kepada masyarakat.

Sementara itu dalam Pasal 14 ayat (1) Undang-undang Nomor 2 Tahun 2002 tentang Kepolisian Negara Republik Indonesia, mengatur tugas Polri, sebagai berikut:

1. membina masyarakat untuk meningkatkan partisipasi masyarakat, kesadaran hukum masyarakat serta ketaatan warga masyarakat terhadap hukum dan peraturan perundangundangan.

2. turut serta dalam pembinaan hukum nasional.

3. memelihara ketertiban dan menjamin keamanan umum.

Tugas pokok Polri adalah memelihara keamanan dan ketertiban masyarakat dan menjamin keamanan umum. Untuk menjalankan tugas pokoknya itu, Polri sebagai salah satu institusi pemerintah dituntut wajib memberikan pelayanan kepada masyarakat telah melaksanakan Reformasi Birokrasi Nasional yang mengacu kepada Permenpan Nomor: Per/15/M.Pan/7/2008, dan Grand Sategy Polri 2005-2025 ditetapkan dengan SK Kapolri No. Pol. Skep/360/VI/2005, tanggal 10 Juni 2005 oleh Kapolri, Jenderal Polisi Drs. Da'i Bachtiar S.H. Grand strategi dibagi dalam tiga tahapan sebagai berikut:

1. Periode 2005-2010 Gelombang pertama membangun kepercayaan (Trust Building). Masyarakat cenderung lebih mendambakan rasa aman dan rasa keadilan. Peningkatan Service quality focus pada kebutuhan tersebut. 
2. Periode 2010-2015 Gelombang kedua menjalin kemitraan (Patnership Building). Tingkat kepuasan terhadap rasa aman dan keadilan diharapkan semakin baik, tuntutan masyarakatakan melebar pada manajemen rasa aman dan adil yang akuntabel, transparan, open dan patuh rule of law.

3. Priode 2016-2025 Gelombang ketiga yaitu polisi yang mumpuni yang bebas dari korupsi kolusi dan nepotisme (Strive for Excellent). Tahap ini kebutuhan masyarakat akan lebih mengharapkan multi dimensional service of quality yang efektif dan efisien di tengah globalisasi kejahatan yang makin canggih.

Eksistensi Kepolisian Sektor merupakan ujung tombak, yang langsung dengan masyarakat untuk memberikan pelayanan dengan wewenang diskresi penuh dalam rangka memeliara keamanan dan ketertiban masyarakat dalam Nagari Kuranji Hilir dan Nagari Koto Tinggi Kecamatan Sungai Limau. Sesuai dengan program pemerintahan JokowiJusuf Kalla telah menetapkan prioritas Nawa Cita, yang telah dilantik tanggal 20 Oktober 2014 , pada program itu terdapat tugas pokok Kepolisian antara lain program (1) yaitu kami akan menghadirkan kembali Negara yang melindungi segenap bangsa dan memberikan rasa aman seluruh warga Negara" dan program (4) yaitu kami akan menolak Negara lemah dan melakukan reformasi system dan penegak hukum yang bebas korupsi, bermartabat dan terpercaya.

Program Nawa Cita (1) dan (4) tersebut dia atas telah dirumuskan secara jelas dalam Undang-undang nomor 2 tahun 2002 tentang Kepolisian Negara Republik Indonesia, baik dalam pasal 2 tentang fungsi kepolisian, serta pasal 13, 14 dan 15 mengenai Tugas Pokok, tugas-tugas dan wewenang Polri, juga KUHP telah mengatur kepastian hukum, Hak Asasi Manusia, transparasi dan akuntabilitas dalam peradilan pidana. Kinerja Polri harus memberi kesan yang baik kepada pimpinan Pemerintahan baru, bahwa Polri sudah melaksanakan reformasi, dalam memelihara keamanan dan ketertiban masyarakat, sebagai alat negara penegak hukum, memberikan perlindungan, pengayoman dan pelayanan kepada masyarakat dan akan terus meningkatkan dan menyempurnakannya kinerja yang proposional (Awaloedin, 2016: 211-212).

Reformasi Birokrasi Polri Gelombang I (Pertama), telah dilaksanakan dari tahun 2004 sampai tahun 2009, dan Polmas dilaksanakan oleh Bhabinkamtibmas dengan Program Quick Wins Polmas kelurahan/desa dan nagari bertujuan 
untuk mewujudkan kemitraan Polri dengan masyarakat, sehingga nantinya mampu mengidentifikasi akar permasalahan, menganalisa, menetapkan prioritas tindakan, mengevaluasi efektifitas tindakan dalam rangka memelihara keamanan, ketertiban dan ketenteraman masyarakat serta peningkatan kualitas hidup masyarakat.

Sedangkan Reformasi Birokrasi Polri Gelombang II (Kedua), Renstra Polri Tahun 2010-2014 Tahap II tentang Partnership Building di bidang Binmas, "Penggelaran Babinkamtibmas/petugas Polmas pada setiap kelurahan/desa dan nagari” sebagai garda terdepan dalam memberikan perlindungan, pengayoman dan pelayanan kepada masyarakat (Pradopo, 2012).

Dewasa ini (hingga penelitian dilakukan) di Kepolisian Resor Pariaman terdapat sebanyak 35 (tiga puluh lima) personil Bhabinkamtibmas yang bertugas membina Kamtibmas yang ditempatkan atau ditugaskan di kelurahan/desa dan nagari.

Penempatan Bhabinkamtibmas di kelurahan/desa dan nagari sesuai dengan Surat Kepala Kepolisian Republik Indonesia Nomor: B/3377/IX/2011, tanggal 29 September 2011 tentang Penggelaran Bhabinkamtibmas di kelurahan/desa dan nagari dan Surat Telegram Kepala Kepolisian Republik Indonesia Nomor: ST/2470/XII/2013, tanggal 24 Desember 2013.

Penempatan Bhabinkamtibmas di kelurahan/desa dan nagari sejalan dengan program Nawacita Presiden Jokowi Dodo yaitu Menghadirkan kembali negara untuk melindungi segenap bangsa dan memberikan rasa aman pada seluruh warga negara.Rencana aksi 100 hari penjabaran program prioritas Kepala Kepolisian Republik Indonesia yaitu pemenuhan satu Bhabinkamtibmas satu kelurahan/desa dan nagari secara bertahap (Tito Karnavian, 2017:72).

\section{METODE PENELITIAN}

Spesipikasi Penelitian ini adalah deskriptif analisis, yaitu penelitian menggambarkan eksistensi.Menurut Suharsimi Arikunto, penelitian deskriptif merupakan penelitian yang dimaksudkan untuk mengumpulkan informasi mengenai status suatu gejala yang ada, yaitu keadaan gejala menurut apa adanya pada saat penelitian dilakukan (Arikunto, 2005: 37). 
Sedangkan menurut Sugiono penelitian deskriptif analisis, adalah penelitian yang memberikan data secara jelas dan teliti mengenai hal yang dipermasalahkan yang kemudian dengan data tersebut dianalisa permasalahan yang ada serta dicari penyelesaiannya berdasarkanperaturan perundang-undangan dan peraturan lainnya yang masih memiliki relevansi dengan penelitian (Sugiono, 2003: 97).

\section{HASIL PENELITIAN}

Eksistensi Kepolisian Sektor dilaksanakan oleh Bhabinkamtibmas untuk Mewujudkan Keamanan dan Ketertiban Masyarakat di Nagari Kuranji Hilir dan Nagari Koto Tinggi Kuranji Hilir Kecamatan Sungai Limau

Kepolisian Sektor Sungai Limau mempunyai dua wilayah Administrasi pemerintahan yaitu Kecamatan Sungai Limau dan Kecamatan Batang Gasan.Penelitian ini dilakukan oleh peneliti di Nagari Kuranji Hilir dengan Bhabinkamtibmasnya Brigadir Fan Hoten dan Nagari Koto Tinggi Kuranji Hilir, Bhabinkamtibmasnya adalah Aiptu Rilpardi Noer.

Pasal 13 Undang-undang Nomor 2 Tahun 2002 tentang Kepolisian Negara Republik Indonesia, menjelaskan tentang tugas pokok Kepolisian Negara Republik Indonesia adalah: Memelihara keamanan dan ketertiban masyarakat; Menegakkan hukum; dan Memberikan perlindungan, pengayoman dan pelayanan kepada masyarakat. Demikian halnya ketentuan Pasal 14 ayat (1) Undang-undang Nomor 2 Tahun 2002:

1. Membina masyarakat untuk meningkatkan partisipasi masyarakat, kesadaran hukum serta ketaatan warga masyarakat terhadap hukum dan peraturan perundang-undangan.

2. Turut serta dalam pembinaan hukum nasional.

3. memelihara ketertiban dan menjamin keamanan umum.

4. Perpolisian masyarakat (Polmas) Model perpolisian yang menempatkan masyarakat bukan semata-mata sebagai obyek tetapi subyek dan mitra kepolisian dalam pemecahan masalah Kamtibmas. Kondisi karakteristik masyarakat di Indonesia merupakan modal awal dan faktor pendukung dalam pembangunan Polmas (Community Policing). Dalam membangun kemitraan diperlukan kepercayaan masyarakat terhadap kinerja polisi baik aspek teknis maupun penegakan hukum.

5. Polmas menjadi aspek strategis dalam membangun kepercayaan masyarakat kepada kepolisian. Kepercayaan inilah yang bila ditumbuhkembangkan pada gilirannya 
menjadi faktor pendukung strategis dalam membangun kemitraan polisi-masyarakat, keberhasilan membangun kepercayaan masyarakat akan berdampak pada keberhasilan membangun kemitraan, demikian sebaliknya. Polmas merupakan salah satu strategi dalam partnership building yang diperlukan dukungan trust building.

6. Penerapan Polmas terkait dengan upaya membangun kerjasama polisi - masyarakat guna menanggulangi kejahatan dan ketidaktertiban sosial dalam rangka menciptakan Kamtibmas,, tidak hanya mencegah timbulnya tetapi juga mencari jalan keluar pemecahan permasalahannya. Dalam konteks ini diperlukan kondisi kepercayaan masyarakat yang kondusif sebagai strategi membangun kemitraan polisi-masyarakat. Untuk itu dibutuhkan unsur-unsur pendukung yakni profesionalisme, implementasi paradigma polisi mitra masyarakat secara proporsional. Strategi tersebut mencakup pembinaan aspek internal maupun eksternal yang relevan dalam mewujudkan kemitraan.

7. Adapun landasan hukum Perpolisian masyarakat meliputi : a. UUD 1945 perubahan Kedua Bab XII Pasal 30 : (1) Tiap-tiap Warga Negara berhak dan wajib ikut serta dalam usaha Keamanan negara. (2) Usaha Keamanan negara dilaksanakan melalui sistem keamanan rakyat semesta oleh Kepolisian Negara Republik Indonesia, sebagai kekuatan utama, dan rakyat, sebagai kekuatan pendukung. b. Undang-Undang No. 2 Tahun 2002 tentang Kepolisian Negara Republik Indonesia, dalam Pertimbangan huruf b ditegaskan bahwa "Pemeliharaan Keamanan Dalam Negeri dilakukan oleh Polri selaku alat negara yang dibantu oleh masyarakat dengan menjunjung tinggi hak asasi manusia".

8. Sedangkan pada Pasal 3 : (1) Pengembangan fungsi kepolisian adalah Kepolisian Negara Republik Indonesia yang dibantu oleh : kepolisian khusus, penyidik pegawai negeri sipil; dan/atau bentuk-bentuk pengawasan swakarsa. (2) Pengemban fungsi kepolisian sebagaimana dimaksud dalam ayat (1) huruf a, b, dan c, melaksankan fungsi kepolisian sesuai dengan peraturan perundang-undangan yang menjadi dasar hukumnya masing-masing. c. Kebijakan dan Strategi Penerapan Model Perpolisian Masyarakat dalam Penyelenggaraan Tugas Polri.) d. Bahwa untuk anev Polmas dilakukan melalui sistem pendataan yang memungkinkan proses analisis dari satuan terbawah Kepolisian Sektor (Polsek) sampai Markas Besar (Mabes Polri) (pasal 54).) 
Dalam Skep/737/X/2005, Polmas menjadi program penuh dari tingkat Polsek sampai Polres, sedangkan pengawasan kegiatan dilakukan hingga tingkat Polda.

Pelaksanaan tugas di desa/kelurahan atau nagari dilaksanakan oleh Bhayangkara Pembinan Keamanan dan Ketertiban Masyarakat yang disingkat dengan (Bhabinkamtibmas). Dalam Buku Pedoman yang dikeluarkan oleh Polri, Peranan Bhabinkamtibmas, adalah:

a. Sebagai Pembimbing masyarakat bagi terwujudnya kesadaran hukum dan Kamtibmas serta meningkatkan partisipasi masyarakat di desa/kelurahan.

b. Sebagai pelindung masyarakat bagi terwujudnya kesadaran hukum dan keamanan ketertiban masyarakat serta meningkatkan partisipasi masyarakat, maka Bhabinkamtibmas menjalankan beberapa kewenanga diantaranya menerima laporan dan/atau pengaduan dari masyarakat dan membantu menyelesaikan perselisihan warga masyarakat yang dapat mengganggu ketertiban umum dengan mengedepankan musyawarah untuk mufakat (alternative dispute resolution) yang dituangkan dalam surat kesepakatan bersama.

c. Sebagai pelindung, pengayom, dan pelayan masyarakat bagi terwujudnya rasa aman dan tentram di masyarakat desa/kelurahan. Dilakukan dengan cara memberikan rasa aman, mensosialisasikan pentingnya Keamanan Lingkungan (Kamling), meronda, sosialisasi bahaya narkoba, terorisme, dan lain-lain penyakit masyarakat.

d. Sebagai mediator, negosiator, dan fasilitatordalam penyelesaian permasalahan sosial yang terjadi di desa/kelurahan. Diantaranya dengan mengantisipasi permasalahan sosial, mencegah dan menanggulangi tumbuhnya penyakit masyarakat yang dilaksanakan melalui kerja sama dengan tokoh masyarakat setempat bersama-sama dengan tokoh masyarakat. Termasuk dalam hal ini mengawasi aliran yang dapat menimbulkan perpecahan atau mengancam persatuan dan kesatuan bangsa dengan meningkatkan partisipasi aktif masyarakat dalam menjaga keamanan dan ketertiban di lingkungannya.

e. Sebagai dinamisator dan motivator aktivitas masyarakat yang bersifat positif dalam rangka menciptakan dan memelihara Kamtibmas. Bhabinkamtibmas menjadi dinamisator dalam setiap kegiatan di Nagari tempat yang bersangkutan bertugas. 
Termasuk menjadi motivator bagi warga masyarakat jika warga tidak menjalankan aktivitas yang produktif.

Kendala Kepolisian Sektor dalam Mewujudkan Keamanan dan Ketertiban Masyarakat di Nagari Kuranji Hilir dan Nagari Koto Tinggi Kuranji Hilir Kecamatan Sungai Limau

Bhabinkamtibmas dalam menjalankan tugas Eksistensi Kepolisian Sekto dalam mewujudkan keamanan dan ketertiban masyarakat di Nagari Kuranji Hilir dan Nagari Koto Tinggi Kuranji Hilir Kecamatan Sungai Limau, berdasarkan hasil wawancara peneliti dengan Bhabinkamtibmas di Nagari Kuranji Hilir, Nagari Koto Tinggi Kuranji Hilir dan Kanit Binmas Ipda Arvi, terdapat beberapa kendala-kendala dalam menjalankan EksistensiKepolisian Sektor dalam mewujudkan Keamanan dan Ketertiban Masyarakat di Nagari Kuranji Hilir dan Nagari Koto Tinggi Kuranji Hilir Kecamatan Sungai Limausebagai berikut:

1. Kendala sarana dan prasarana, dalam menjalankan Eksistensi Bhabinkamtibmas, tidak tersedianya Pos Polisi di Nagari, padahal Bhabinkamtibmas harus menerima laporan dan pengaduan dari warga masyarakat. Pos Polisitersebut sangat diperlukan untuk menyelesaikan permasalah masyarakat, dalam rangka problem solving, termasuk ruang untuk merumuskan penyelesian permasalahan masyarakat.

2. Kendala paradigma warga, masih menggunakan cara berpikir tradisional, yang masih takut jika berhadapan dengan Polri. Hal ini menyulitkan tugas Bhabinkamtibmas dalam menyelesaikan masalah-masalah sejak dini.

3. Kendala kesadaran hukum warga yang cenderung berpandangan pendekatan menang kalah (win lose solution) dalam satu masalah. Belum terbiasa menggunakan pendekatan win-win solution dengan mengedepankan musyawarah untuk mufakat (alternative dispute resolution). Termasuk masih juga menggunakan jasa-jasa orang-orang 'pintar' untuk menyelesaikan masalah.

4. Kendala luas wilayah, demografi dan geografi Nagari Kuranji Hilir dan Nagari Koto Tinggi Kuranji Hilir yang memiliki bukit, sungai, dan lurah. Demikian halnya perbandingan satu Bhabinkamtibmas dengan jumlah warga yang berkisar 3.000 jiwa. 
5. Kendala yang berasal dari Kompetensi Bhabinkamtibmas, misalnya dalam hal kemampuan berkomunikasi satu arah, tidak mahir berkomunikasi, sehingga ada pesan-pesan yang tidak sampai ke warga saat menjalin komunikasi.

Upaya-Upaya Yang Dilakukan Oleh Kepolisian Sektor Untuk Mengatasi kendala dalam Mewujudkan Keamanan dan Ketertiban Masyarakat di Nagari Kuranji Hilir dan Nagari Koto Tinggi Kuranji Hilir Kecamatan Sungai Limau

Untuk menanggulangi kendala-kendala Eksistensi Kepolisian Sektor dalam mewujudkan keamanan dan ketertiban di Nagari Kuranji Hilir dan Nagari Koto Tinggi Kuranji Hilir Kecamatan Sungai Bhabinkamtibmas perlu mengambil langkahlangkah sebagai berikut :

1. Upaya-upaya yang dilakukan untuk mengatasi Kendala sarana dan prasarana, adalah mengusulkan kepada Wali Nagari Kuranji Hilir dan Wali Nagari Koto Tinggi Kuranji Hilir untuk dapat membangun Pos Polisi yang nantinya dipergunakan oleh Bhabinkamtibmas untuk menerima laporan dan pengaduan warga masyarakat. Pos Polisi tersebut sangatberguna oleh Bhabinkamtibmas untuk menyelesaikan permasalah masyarakat, dalam rangka problem solving, termasuk merumuskan arah kebijakan penanggulangan gangguan kamtibmas yang akan terjadi.

2. Upaya-upaya yang dilakukan untuk mengatasi Kendala paradigma warga, adalah Bhabinkamtibmas melakukan penyuluhan hukum dan bimbingan rohani, dilaksanakan yang bekerjasama dengan tokoh agama. Bimbingan rohani dilaksanakan dalam bentuk wirid remaja satu kali dalam satu minggu yaitu setiap hari kamis malam.

3. Upaya-upaya yang dilakukan untuk Kendala kesadaran hukum warga yang cenderung berpandangan pendekatan menang kalah (win lose solution) adalah selain daripada memberikan penyuluhan hukum, masyarakat juga dilibatkan oleh Bhabinkamtibmas dalam menentukan arah kebijakan Kamtibmas, sehingga mereka mengerti dan paham tentang arti pentingnya keamanan dan ketertiban dalam kehidupan sehari-hari.

4. Upaya-upaya yang dilakukan untuk mengatasi Kendala luas wilayah, demografi dan geografiadalah Kepolisian Sektor Sungai Limau perlu menambah personil 
Bhabinkamtibmas, sehingga tidak terjadinya kejenuhan dari Bhabinkamtibmas dalam melayani masyarakat binaannya.

5. Upaya-upaya yang dilakukan untuk mengatasi Kendala yang berasal dari Kompetensi Bhabinkamtibmas, adalah perlu dilakukan penambahan pendidikan kejuruan bagi Bhabinkamtibmas yang ditugaskan dinagariseperti pendidikan kejuruan Bhabinkamtibmas ke Pusdik Binmas Banyu Biru Semarang sehingga mereka mampu menjalankan tugasnya sesuai dengan kehendak masyarakat.

\section{PENUTUP}

Berdasarkan analisis dan pembahasan di atas, maka didapat beberapa kesimpulan sebagai berikut:

1. Eksistensi Kepolisian Sektor dalam mewujudkan keamaman dan ketertiban masyarakat di Nagari Kuranji Hilir dan Nagari Koto Tinggi Kuranji Hilir Kecamatan Sungai Limau, dilaksanakan oleh Bhabinkamtibmas sebagai alat Negara penegak hukum, pelindung, pengayom, dan pelayan masyarakat serta memelihara Kamtibmas.

2. Kendala-kendala Eksistensi Kepolisian Sektor dalam mewujudkan keamaman dan ketertiban masyarakat di Nagari Kuranji Hilir dan Nagari Koto Tinggi Kuranji Hilir Kecamatan Sungai Limau, adalahKendala non-yuridis diantaranya sebagai berikut : a). Belum terwujudnya sumber daya manusia profesional, modern dan terpercaya untuk memberikan pelayanan prima kepada masyarakat. b). Belum tersedia sarana dan Prasarana yang memadai pada Kepolisian Sektor, seperti Pos Polisi di Nagari, sebagai untuk problem solving, dalam menyelesaikan permasalahan masyarakat. c). Belum ada sistem pengawasan internal yang baik untuk mendukung kinerja Kepolisian Sektor. Pengawasan internal yang berjalan baik dan efektif akan mencegah munculnya penyimpangan-penyimpangan yang pasa akhirnya mengurangi bobot kredibilitas lembaga Kepolisian di mata masyarakat. Mekanisme pengawasan harus dilakukan secara terpadu, yaitu dengan pendekatan kelembagaan (institutional approach) yang dilakukan oleh internal kelembagaan dan pendekatan sistem (system approach) yang meletakkan unsur eksternal dan masyarakat sebagai bagian dalam sistem pengawasan. d). Kendala paradigma warga, masih menggunakan cara berpikir lama, kesadaran hukum warga yang belum terbiasa menggunakan pendekatan win-win solution 
dengan mengedepankan musyawarah untuk mufakat (alternative dispute resolution). Luas wilayah, demograpi dan geograpi, dan Kendala yang berasal dari kekurangan personil dan kompetensi Bhabinkamtibmas.

3. Upaya-upaya Eksistensi yang dilakukan oleh Bhabinkamtibmas dalam mewujudkan keamaman dan ketertiban masyarakat nagari, adalah mengusulkan kepada Wali nagari untuk dapat membangun Pos Polisi sebagai sarana dan prasarana Bhabinkamtibmas sebagai tempat menerima laporan/pengaduan warga masyarakat dan tempatproblem solving. Penyuluhun hukum secara berkala dan terencana kepada warga, mengikutsertakan masyarakat dalam penyelesaian masalah, mengusulkan penambahan jumlah pesonil Bhabinkamtibmas dan meneningkatan kompetensi Bhabinkamtibmas melalui peningkatan: pengetahuan, keterampilan, dan sikap kepribadian.

\section{DAFTAR PUSTAKA}

\section{Buku Teks :}

Awaloedin Djamin, Masalah Aktual Kepolisian, Yayasan tenaga Kerja Indonesia Pusat Pembinaan Sumberdaya Manusia, Jakarta 2016

Burhanuddin, Hukum, Politik dan Tujuan Negara, Kanisius. Yogyakarta, 2003

Indroharto, Usaha Memahami Undang-Undang Tentang Peradilan Tata usaha Negara, Pustaka Sinar Harapan, Jakarta, 1991

Mirza Nasution. Negara dan Konstitusi, FH-Universitas Sumatera Utara, Medan. 2004

Moch. Mahfud MD, Hukum dan Pilar-pilar Demokrasi, Gamma Media, Yokyakarta, 1999 Demokrasi Hak Asasi Manusia dan Masyarakat Madani, Tim ICC UIN Jakarta, 2003

Demokrasi dan Konstitusi di Indonesia, Rineka Cipta, Jakarta, 3003

Mustamin Daeng Matutu. Al Kajangi, e.al, Mandat, delegasi, Attribusi dan Implementasinya di Indonesia, UII Press, Yogyakarta, 2004

Muhammad Tito Karnavian dalam pusaran Terorisme, Media Pressindo Yokyakarta, 2017.

Otong Rosadi, Hak Anak Bagian dari Hak Asasi Manusia (HAM), Wildan Akademika, Subang, 2004,

Philipus M. Hadjon, et.al, Hukum Administrasi dan Tindak Pidana Korupsi, Gadjah Mada University Press, Yogyakarta, 2011

Ridwan, HR., Hukum Administrasi Negara, PT. Raja Grafindo Persada, Jakarta, 2006 
SF. Marbun, Peradilan Administrasi Negara dan Upaya Administrasi di Indonesia, Liberty, Yogyakarta, 2003. , Hukum Administrasi Negara I, FH UII Press, Yokyakarta 2012.

Soediman Kartohadiprodjo, Indonesia Negara Hukum, Seminar Ketatanegaraan UUD 1945, Seruling Masa, Jakarta, 1996

Sugiono, Metode Penelitian Ilmu Sosial, Alfabeta, Bandung. 2003

Suharsimi Arikunto, Metode Penelitian, Alfabeta, Bandung. 2005

Suwoto Mulyosudarmo, Peralihan Kekuasaan, Kajian Teoritis dan Yuridis Terhadap Pidato Nawaksara, PT. Gramedia Pustaka Utama, Jakarta, 1997

Tim ICC UIN Demokrasi Hak Asasi Manuasia dan Masyarakat Madani, Jakarta, 2003

Timur Pradopo, Strategi manajemen perubahan Mind Set dan Culture Set Polri, Desember 2012.

\section{Peraturan Undang-Undang :}

Undang-Undang Dasar Negara Republik Indonesia Tahun 1945.

Undang-Undang Dasar Negara Republik Indonesia 1945 Pasal 30 ayat (4) tentang Pertahanan dan Keamanan Negara.

Undang-Undang Nomor 2 Tahun 2002 tentang Kepolisian Negara Republik Indonesia. 